\title{
Tax Awareness of the Conceptions of Tax Compliance within Surabaya Society: A Study in Surabaya, Indonesia
}

\author{
Daniel Pandapotan ${ }^{1 *}$, Christine Tjen $^{2}$ \\ ${ }^{1}$ Faculty of Economics and Business, Universitas Indonesia, Jakarta 10430, Indonesia \\ ${ }^{2}$ Faculty of Economics and Business, Universitas Indonesia, Depok 16424, Indonesia \\ *danielpandapotan12@gmail.com
}

\begin{abstract}
This research aimed to describe the tax awareness in the society of Surabaya located in District Mulyorejo as one of five districts which had tax arrears of about Rp31 billion. This research used a qualitative research method with a phenomenology paradigm. Informants in the study were citizens in District Mulyorejo who had experience of paying tax and so met the criteria for being taxpayers. All data in this study were collected through structured in-depth interviews with the informants and analyzed by Milles and Huberman's analytical technique. The results showed that the participants had an awareness of taxation that encouraged them to dutifully pay the tax on land and buildings annually although they wanted to know how to calculate the taxes. They also suggested the government should improve its performance regarding tax collection methods, so that the society can trust the government to manage the tax.
\end{abstract}

Keywords: Land and Buildings Tax, Taxation, Tax Awareness, Tax Compliance.

\section{INTRODUCTION}

The autonomy of local authorities has consequences for the funding requirements of local governments in the implementation of activities in the area. A shortage of funding for development activities in the area will make regional autonomy a burden as well as an obstacle to development of the region, so the financial balance needs to be determined. Implementation is done through a financial balance consisting of fund-sharing, the General Allocation Fund ("DAU”), and the Specific Allocation Fund ("DAK”), as stipulated in Law No. 33 of 2004,2. One form that is the embodiment of fund-sharing is land and buildings tax, which can be categorized as a system of balanced allocation based on the producing regions ${ }^{3}$.

Land and buildings tax, as stated in Law No. 28 of $2009^{4}$, was until December 31, 2013, still the responsibility of the Directorate General of Taxation. However, the city received only a $64.8 \%$ share of the total property taxes which had been successfully collected. Then, as of January $1^{\text {st }}, 2014$, responsibility for the collection of land and buildings tax was transferred to the district or city and went into the revenue for local government ${ }^{5}$.

Surabaya Municipality is one of the local governments that have collected land and buildings taxes independently as part of the source of revenue in their budget since 2011. Local Regulation No. 10 of 2010 and the Instruction of Surabaya Mayor No. 13 of 2010 are the implementing rules for collecting land and building tax.

The revenue from land and buildings tax collection in Surabaya in 2013 reached only 85.36\% or Rp 606 billion $^{6}$. In 2012, land and buildings tax collection was only $72.38 \%$ or Rp572 billion ${ }^{7}$. Then, for 2011 , land and buildings tax collection was only $70.23 \%$ or Rp498 billion. Thus, the Surabaya local government did not obtain any significant revenue from land and buildings tax despite having full authority to levy tax on land and buildings.

Sub-district Mulyorejo is one of five districts in Surabaya, and has the largest amount of uncollected land and buildings taxes, reaching IDR31 billion between 2000 and 2009 before the collection of tax on land and buildings was delegated the local government ${ }^{7}$. Thus, amount of large tax arrears can indicate that the residents of Subdistrict Mulyorejo lack awareness of public taxation.

The factors affecting the success of tax revenues are tax payer, tax law, and tax administration ${ }^{8}$. The factor of tax payer is linked to the taxpayer and cannot be controlled, while tax law, tax policy, and tax administration are factors that can be controlled. This is the basis of this study, which aims to examine the existing tax payer factor which allegedly affects taxpayers, both individuals and entities related to tax compliance. Hence, the tax payer factor will be examined in this study regarding the taxation awareness of the Surabaya public, in particular the subdistrict of Mulyorejo.

Suyatmin's research ${ }^{8}$ showed that awareness of taxation has a significant effect on the level of tax compliance of land and buildings tax. Previous research by Fratenersi ${ }^{9}$ concluded that awareness of taxation affects the successful collection of revenue from the land and buildings tax of Bengkulu city. Sholichah and Istiqomah's research ${ }^{10}$ supported the findings that the level of awareness and understanding of taxation affect the successful 
collection of revenue from the property tax.

\section{LITERATURE REVIEW}

\section{Tax Awareness}

The awareness of taxation is a condition where taxpayers know and understand about the tax and fulfil tax obligations. Awareness of taxation also indicates that taxpayer sensitivity with regard to the taxation aspect is strongly influenced by perceptions of the tax itself ${ }^{11}$.

Soemarso ${ }^{12}$ stated that low public awareness of taxation often becomes one of the many causes that potential tax not collected. Taxpayer awareness regarding paying taxes is associated with the perception of the paradigm about tax functions for financing development, tax purposes for the provision of public goods, as well as justice (fairness) and legal certainty in the fulfillment of tax obligations ${ }^{13}$.

Kirchel ${ }^{14}$ revealed that one of the things that motivate taxpayer to comply with tax obligations in the implementation is the lack of awareness regarding tax functions and duties as citizens. According to Manik's ${ }^{15}$, criteria taxpayer is said be conscious of the following: knowing the existence of laws and tax regulations; knowing the tax function for state financing; understanding that tax obligations must be carried out in accordance with applicable regulations; counting, paying, reporting tax voluntarily; and counting, paying, and reporting tax correctly.

\section{Tax Compliance}

Tax compliance is defined as a state where the taxpayers fulfill all the tax obligations and exercise the rights of taxation $^{16}$. There are two types of compliance: formal compliance and adherence material ${ }^{16}$. Formal compliance is a condition where the taxpayers formally meet the tax obligations in accordance with the provisions of the tax laws. Adherence material is a condition where the taxpayer fulfils all tax obligations.

The criteria of tax compliance ${ }^{17}$ are as follows:

a. the timely submission of the notice

b. no tax arrears for all types of taxes, except the installment tax arrears licensed or deferred payment of taxes

c. financial statements audited by a public accountant or financial supervisory agencies with unqualified opinion for 3 (three) consecutive years

d. taxpayer not convicted of a criminal act in the field of taxation based on the court's decision, which is binding within a period of the last 5 (five) years.

\section{RESEARCH METHOD \\ Research Approach}

The research was carried out by the researchers using a qualitative research approach. Qualitative research is research procedures that produce descriptive data in the form of written or spoken data and observed behaviors ${ }^{18}$. In qualitative research, the researchers must not isolate the individual or organization from the variable or the hypothesis, but instead, must see it as a whole ${ }^{18}$.

The reason for using a qualitative research approach in this study is because problems about the low revenue from land and buildings tax in the city of Surabaya are directly connected with the meaning of the narrative through the statement that society in the sub-district of Mulyorejo as taxpayers, the people should demonstrate tax compliance.

\section{Informant Selection}

The study took place from April 2013 until June 2013 at the sub-district of Mulyorejo as one of the areas with the lowest revenue from land and buildings tax or the largest tax arrears in the city of Surabaya. However, this study is only able to collect data from informants who dutifully pay land and buildings tax, because the informants who do not pay taxes on land and buildings were not willing to participate. Therefore, this study aims to identify the forms of tax public awareness of people in the sub-district of Mulyorejo that encourages them to pay their taxes dutifully. 
Table.1. Informant Information

\begin{tabular}{ccc}
\hline Name & Sector & Occupation \\
\hline Informant 1 & Kalijudan & Enterpreneur \\
Informant 2 & Kalijudan & $\begin{array}{c}\text { Directorate General } \\
\text { Tax Retirement } \\
\text { Enterpreneur }\end{array}$ \\
Informant 3 & Mulyorejo & East Java Province \\
Informant 4 & Mulyorejo & Officer \\
Informant 5 & Mayarsabrangan & Enterpreneur \\
Informant 6 & Manyarsabrangan & Enterpreneur \\
Informant 7 & Dukuh Suterejo & Enterpreneur \\
Informant 8 & Dukuh Suterojo & The retired of private \\
& & sector \\
\hline
\end{tabular}

The criteria for the selection as informants of this study as follows: (1) the eight informants had paid their land and buildings tax for more than three years without sanctions, whether criminal penalties or administrative sanctions; (2) the eight informants always paid the land and buildings tax on time and had paid property tax in 2011 and 2012; (3) the land or buildings which informants used were certified or had official permission, so that the land or buildings were taxed, meaning the eight informants had the experience of meeting their tax obligations.

\section{Phenomenology as A Research Perspective}

Phenomenology is an approach which assumes that the phenomenon is not a stand-alone reality. The phenomenon appears to be a full object with a transcendental meaning. In the social world where humans live, life is intersubjective and meaningful ${ }^{19}$. Thus, the phenomenon is understood by humans as a reflection of the transcendental experience and understanding of the meaning ${ }^{19}$.

Research with a phenomenological approach seeks to understand the meaning of the various events and human interaction in the particular situation. The research thus begins with silence and opens without prejudice. This means that researchers do not consider themselves to know the meaning of the various events that happen and there are people who are being studied ${ }^{20}$.

This research used the phenomenology paradigm because the research wants to see the public awareness of taxation in the sub-district of Mulyorejo, Surabaya, which was formed from the experience of the people themselves when paying tax on land and buildings and following the administration in the fulfillment of tax obligations.

\section{Analysis Technique}

The data analysis technique used in this research is the Miles and Huberman data analysis. This analysis technique consists of three activities simultaneously: data reduction, data presentation, and conclusion ${ }^{18}$.

Data reduction is the process of selecting, concentrating, attenting, abstracting, and transforming raw data from the field. This process takes place during the research carried out throughout the study. In the reduction process, researchers are seeking valid data obtained from informants encountered in the field activities during the research.

Presentation of data is a set of structured information that makes it possible to draw conclusions and take action. The forms of presentation are narrative text, matrices, graphs, networks, and charts. The purpose of the presentation of data is to facilitate researchers to read the data and draw conclusions.

The researcher's conclusion will be verified during the study. Meanings that emerge from the data should always be tested so the validity of the data is assured. In the concluding stage, the researcher will formulate propositions related to the principles of logic, identified as research findings, followed by a discussion with reference to existing data, the grouping of the data, and propositions.

\section{RESULT AND DISCUSSION}

\section{The Knowledge of Tax function as a Foundation of Awareness}

Awareness is a human element for understanding reality and the way to act and behave. Tax is an obligation for every taxpayer. The tax awareness understanding is based on the taxpayer's knowledge about tax function. Therefore, the taxpayer is expected to have no negative perception about the tax imposed upon them.

Based on interviews with eight informants on knowledge about tax function or tax benefits, it was found that the informants who worked as government officers, private employees, and entrepreneurs knew that the tax is a financing source used by the government for development. They understood that the absence of the tax would make it difficult for the government to provide for the society's welfare. 
Two informants did not know the tax function although both informants still paid tax on land and buildings in a timely manner. The taxpayer should have taxation knowledge as a foundation for helping the taxpayer to perform their tax obligations.

\section{The Taxation Awareness Is the Willingness to Pay and Report Tax}

Tax is one of the citizen's obligations, as it means the state can continue to provide shelter, security, and welfare, and develop the existing public facilities, so the taxpayer is still required to pay taxes. However, the taxes imposed by the state on the taxpayers are interpreted from this perspective and demonstrate their different attitudes or actions $^{21}$.

Spending money for tax payments will be favored when taxpayers spend money to pay taxes; the government should provide contra-performance considered in balance with the money paid. Obviously, this is difficult and it does not make sense, because the huge number of taxpayers and the nominal amounts of tax differ from one taxpayer to another. In addition, the government should think and provide directly contra-performance in accordance with the value of money received from the taxpayer as payment of the $\operatorname{tax}^{21}$.

Based on the interviews, all informants demonstrated a willingness to pay taxes though to different degrees. They realized that they would be participating in the implementation of developments for the benefit of the community in the city of Surabaya, their place of residence.

Irianto $^{22}$ described that one of the reasons that encourage taxpayers to pay tax is an awareness of participating in development. Realizing this, taxpayers want to pay taxes because they benefit from the tax collection. They realize that the tax will be used for the development of the country and for improving the citizens' welfare. The willingness to pay taxes was due to an awareness of the need to pay taxes. Thus, an awareness of taxation has provided evidence that the eight informants fulfilled their tax obligations, i.e., regarding the absence of taxation or the imposition of tax arrears in 2012.

\section{The Informants' Awareness of Taxation and the Reality of the Surabaya Government's Effort to Collect Tax}

The tax socialization campaigns conducted by the tax authorities are a way to increase the awareness of taxation for taxpayers. This can be achieved through advertising in mass media, counseling, and training. Kurniawan ${ }^{23}$ explained the problem of low taxation awareness is that the tax counseling is not optimal, so many potential taxes are not gathered.

All informants claimed that Surabaya city government was not doing its best to raise awareness through the dissemination of taxation or a change in the nominal concerning land and buildings tax payment and the defined status of the land and buildings with Green Letters. Therefore, some informants criticized the performance of Surabaya city government's attempts to raise taxation awareness among Surabaya society.

One of critical issues noted by some informants is that of the Green Letter. The Green Letters are the consequence of the nationalization of land to become a government asset. The enforcement status of land and buildings based on Green Letters makes the community pay a levy (rent) and the Land and Buildings tax ${ }^{24}$. In other words, citizens are required to bear two payments on their occupied buildings. In fact, the status of the land with the Certificate of Use Rights or the proprietary rights imposes only the land and buildings tax. This represents a great provocation for society.

The taxpayers' knowledge about the calculation of land and buildings tax has a great influence on tax compliance ${ }^{25}$. Therefore, the Department of Revenue and Finance Management of Surabaya government and the sub district government officer have an obligation to provide education or training to improve Surabaya society's knowledge about tax.

\section{CONCLUSION \\ Research Conclusion}

Taxation awareness is the most important component of realizing tax compliance in the implementation of tax obligations. The achieved awareness in terms of research involves knowing the tax function, willingness to pay, reporting tax on land and buildings, and paying and reporting taxes correctly.

Relating knowledge of tax function to taxation awareness, six informants already knew the tax function as a source for financing development. Meanwhile, two informants did not know the function of the tax, and one informant gave a negative opinion about the tax, meaning they were not able to answer the interview questions.

Meanwhile, with regard to willingness to pay and tax reporting as an indication of awareness, this study had three major findings. First, the willingness to pay taxes is linked to the process being regulated by law. Second, the willingness to pay taxes for helping involves the implementation of development in the city of Surabaya. Third, the willingness to pay and report tax and paying taxes occurs through the teachings of religion or obeying the commands of religion.

This study also managed to establish the basic facts that not all the informants felt that the Surabaya government 
had made a real effort to raise the awareness of taxation. There has never been any counseling or training in taxation, and there is not even any information about a change in the nominal amount of land and buildings tax payable. Some informants raised the issue of the status of their homes, which are still subject to Green Letter because they felt that they were still subject to land and buildings taxes and the nominal is increasing without them having any certainty over their rights.

\section{Research Implication}

The forms of awareness identified in this research show that self-awareness results from the individual taxpayer. The taxpayers meet their tax obligations because they hope the authorities or government as tax managers will provide welfare in an equitable development for all parties and the tax revenue is not abused.

The seriousness of local government's intention to utilize the land and buildings tax as a source of revenue (PAD) must be presented to people who willingly and dutifully pay taxes while maintaining compliance. In addition, the local government can reduce the serious issues of tax avoidance because people feel the real benefit from tax.

\section{Research Limitation}

This study has several limitations. The main limitations are as follows. This study aims only to understand the opinions and attitudes of the informants regarding the awareness of taxation in accordance with the position or profession respectively, and is not trying to express their perceptions of the implementation of tax obligations.

A second limitation is that informants from the society in the sub-district of Mulyorejo are not those that do not always pay land and buildings tax on time, so the main factor regarding the lack of awareness about not paying taxes and the realization that this leads to a lower revenue from land and buildings tax in the sub district of Mulyorejo is not identified although this study did not aim to answer this question.

Finally, this study describes only the understanding of the taxpayers, but does not provide an explanation from the perspective of the Department of Revenue and Finance Management in Surabaya or from officers of the subdistrict and village. So in future research, it is expected that the authorities will also participate so he Surabaya government will understand the condition of society members as taxpayers of land and buildings tax.

\section{REFERENCES}

[1] Republik Indonesia. Undang-Undang RI No. 33 Tahun 2004 tentang Perimbangan Keuangan antara Pemerintah Pusat dan Daerah.

[2] Mardiasmo. Otonomi daerah sebagai upaya memperkokoh basis perekonomian daerah, Downloaded on 26 January 2013 , http://www.ekonomirakyat.org/edisi4/artikel3.htm (2002).

[3] M. Ikbal. Diskriminasi dana perimbangan dan menuju pola desantralisasi fiskal yang berkeadilan, Proceeding of Simposium Akuntansi XIV, Bidang: Akuntansi Sektor Publik (2011).

[4] Republik Indonesia. Undang-Undang Nomor 28 Tahun 2009 tentang Pajak Daerah dan Retribusi Daerah.

[5] Direktorat Jendral Pajak. Pengalihan Pajak Bumi dan Bangunan Perdesaan dan Perkotaan (PBB-P2) sebagai pajak daerah, Downloaded on 4 February 2013, http://www.pajak.go.id (2012).

[6] Surabaya Post. Realisasi PBB hanya 73 persen, Downloaded on 6 February 2013, http://www.surabayapost.co.id (2013).

[7] Antara Jatim. Realisasi pajak daerah Surabaya capai 85,9\%, Downloaded on 20 January 2013, http://www.jatim.antaranews.com (2011).

[8] Suyatmin. Pengaruh sikap Wajib Pajak terhadap kepatuhan Wajib Pajak dalam pembayaran Pajak Bumi dan Bangunan, Tesis: Universitas Diponogoro, Semarang (2004).

[9] Fraternesi. Studi empiris tentang pengaruh faktor-faktor yang melekat pada Wajib Pajak terhadap tingkat keberhasilan penerimaan Pajak Bumi dan Bangunan Kota Bengkulu, Tesis: Universitas Diponogoro, Semarang (2002).

[10] M. Sholichah, and Istiqomah. 2005. Perilaku Wajib Pajak terhadap tingkat keberhasilaan penerimaan Pajak Bumi dan Bangunan, Jurnal Logos, 3(1) (2005).

[11] Indonesia Tax Review. 1000 Alasan untuk Total Tax Awaraness, Lembaga Manajemen Formasi, 4(20) (2005) 42.

[12] S. B. Soemarso. Perpajakan: pendekatan komperhensif, Penerbit Salemba Empat, Jakarta (2007).

[13] B. Torgler. Introduction to the special issue on tax compliance and tax policy, Economic Analysis and Policy 38 (1), The School of Economics and Finance, Queensland University of Technology, Australia (2008).

[14] E. Kirchler. Enforced versus voluntary tax compliance, Journal of Economic Psyhcology, 29 (2009) 210-255.

[15] A. Manik. Pengaruh kualitas pelayanan, biaya kepatuhan pajak, dan kesadaran Wajib Pajak pada kepatuhan pelaporan Wajib Pajak Badan yang terdaftar di Kantor Pelayanan Pajak Madya Denpasar, Skripsi: Universitas Udayana, Denpasar (2009).

[16] S. Nurmantu. Pengantar Perpajakan, Kelompok Yayasan Obor, Jakarta (2003).

[17] Kementerian Keuangan. Peraturan Menteri Keuangan Nomor 192/PMK.03/2007 tentang Tata Cara Penetapan Wajib Pajak dengan Kriteria Tertentu dalam Rangka Pengembalian Pendahuluan Kelebihan Pembayaran Pajak.

[18] Basrowi and Suwandi. Memahami penelitian kualitatif, PT Penerbit Rineka Cipta, Jakarta (2008).

[19] Little John. Theories of human communication: eighth edition, Thomson Wardsworth, Canada (2005).

[20] H. B. Sutopo. Metode penelitian kualitatif: teori dan aplikasinya dalam penelitian, Sebelas Maret University Press, Surakarta (2002).

[21] A. Tuasamu. Kepatuhan pajak dalam perspektif keadilan menurut pandangan dosen di Ambon, Publikasi Ilmiah, Universitas Brawijaya, Malang (2010).

[22] T. Vanessa and P. H. Adi. Dampak program Sunset Policy terhadap faktor-faktor yang mempengaruhi kemauan membayar, Makalah Simposium Nasional Perpajakan II, Universitas Trunojoyo, Bangkalan (2009).

[23] R. Kurniawan. Sadar pajak: kunci pembangunan, Lomba Karya Tulis, Direktorat Jendral Pajak dan Fisip UI, Jakarta (2004). 
[24] W. S. Dharma, Wahyu Surya. Dinamika Rakyat Anti Surat Ijo Surabaya (Geratis), Jurnal Politik Indonesia Edisi Juli-September 2012, 1(1) (2012) 45-51.

[25] A. Tristiyana. Pengaruh pengetahuan Wajib Pajak tentang Peraturan, Cara Penghitungan, dan Sanksi Pajak Bumi dan Bangunan terhadap kepatuhan membayar Pajak Bumi dan Bangunan (studi kasus di Perum Benteng III Yogyakarta), Skripsi: Universitas Pembangunan Nasional “Veteran”, Yogyakarta (2011). 